\title{
The Status of Vultures Neophron Percnopterus, Gypaetus Barbatus, Gyps Fulvus, Aegypius Monachus (Accipitriformes) in Azerbaijan
}

\author{
Tahir Karimov ${ }^{1}$ and Arzu Mammadov ${ }^{2}$ \\ ${ }^{1}$ Azerbaijan National Academy of Sciences, Institute of Zoology (Ornithology Department), \\ Azerbaijan, Baku, str. A.Abbaszade. AZ 1004, pass.1128, block 504, Azerbaijan. \\ ${ }^{2}$ Azerbaijan National Academy of Sciences of Institute of Bioresources Nakhcivan Department of NAS \\ of Azerbaijan Nakhchivan AZ 7000. str. Babek 10, Azerbaijan.
}

E-mail: tahirornit@mail.ru; arzumammadov65@mail.ru

Received: 25.11.2019. Accepted: 10.12.2019

\begin{abstract}
The inventory of vultures was conducted in 2004-2016. Modern areal and nesting places of Griffon vulture (Gyps fulvus), Black vulture (Aegypius monachus), Egyptian vulture, (Neophron percnopterus) and Bearded vulture (Gypaetus barbatus) in Azerbaijan was determined. Our results reveals that $60.6 \%-i(n=20)$ of nesting locations were found in Lesser Caucasus, $36.3 \%-i(n=12)$ in Great Caucasus, $3.0 \%-i(n=1)$ in Talysh mountains. Over the last 13 years the total known population of these species decreased by $15.3 \%$. Primary reason of this decline is the abandonment of livestock farms and graze lands, accompanied by the expansion of cultivated areas $(P<0.0001)$ since large domestic ruminants are important source of food for Griffon vultures,. The other important threats to these species were identified as nestling removal, capture and trade of wild birds for exhibiting them in zoological gardens and roadside restaurants, destructing the nests of Black vultures, ecotourism and recreation has impacted on the decrease in the number of Griffon vultures ( $\mathrm{P}<0.0001$ ). In 2016, 61 pairs of Griffon vulture, 59 pairs of Egyptian vulture, 16 pairs of Black vulture, 9 pairs of Bearded vulture were recorded in the territories of Azerbaijan.
\end{abstract}

Key words: Vultures; Breeding survey; Population; Threats; Azerbaijan

\section{Introduction}

A global catastrophe in vulture populations is evident and emerges as a priority in global nature conservation agenda. Over the last few decades, vulture populations have declined at high rates, especially in Asia and Africa and are now the single most threatened avian functional guild, known as obligate scavengers, in the world. (Buechley and Şekercioğlu, 2016). For conservation of Griffon vulture, Egyptian vulture, Bearded vulture and Black vulture in Europe and Asia numerous projects and conservation implications are carried out. European Vulture populations have been declining and the reasons for population declines are likely a combination of several known threats such as poisoning, electrocution, landscape changes, graze land management regimes and direct persecution (Sara et al., 2009; Donázar et al., 2010; Angelov et al., 2012; Margalida et al., 2012; Carrete et al., 2013; Ankumarev et al., 2014; Moreno - Opo et al., 2015; Cortes-Avizanda et al., 2016; Oppel et al., 2016; Ogada et al., 2016; Velevski et al., 2016; Katzenberger et al., 2017).

Azerbaijan is a country in Caucasus, where four species of vultures breed. Black vulture, Griffon vulture and Bearded vulture are considered a resident bird species while Egyptian vulture is a summer migrant (Patrikeev, 2004). The size and distribution of Azeri vulture populations are poorly documented, with majority of research papers published earlier than 1993 and there are no systematically collected data published since then (Patrikeev, 2004). The breeding locations, size of the population and threats to those species still remains poorly documented and the current status of Vultures in Azerbaijan are not properly assessed or they were assessed based on poor data quality (Botha et al., 2017). We have conducted a national breeding inventory of vultures and investigated the drivers of the population decline of those four species. The results of the 12 years long research work from 20042016 are presented in this paper.

\section{Materials and Methods}

\section{Study area, registration of nests and anthropogenic factors bird couting}

Our research focuses on Griffon vulture (Gyps fulvus Hablizl, 1783), Black vulture (Aegypius monachus Linnaeus, 1766), Egyptian vulture (Neophron percnopterus Linnaeus, 1758) and Bearded vulture (Gypaetus barbatus Linnaeus, 1758). 
In Azerbaijan $\left(39^{\circ} 24^{\prime}, 41^{\circ} 54^{\prime} \mathrm{N}, 44^{\circ} 46^{\prime}, 50^{\circ} 45^{\prime} \mathrm{E}\right)$ the census of these species was conducted in mostly three geographical units, which are Great Caucasus, Lesser Caucasus and Talysh mountains from 2004 to 2016 (Figure 1).

The research team had implemented the line transects methods by Osmolovskaya and Formozov (1952) and Abuladze (1989) Logging of birds in mountainous conditions on flat and mountainous landscapes. Later we have modified our transects with point counts by using the method of Logging of distribution and number of raptor birds» by Sultanov et al. (2008). We have conducted 66 individual surveys to identify the breeding locations on the first year of the study, in 2004. During the surveys, we have benefited from the help and experience of reserve and forestry workers and shepherds in detecting the nesting locations. In each case, we have identified the nesting location. When the nest is found, we have recorded the physical properties of the nests (height, exposition), the plant communities and geological characteristics of the site. The coordinates of the nesting places were determined and their map was generated. We have organized 82 surveys during 2004-2016 for monitoring of the population. The vultures' behavior and the various breeding evidence in the nests were recorded to study the size of the population and population dynamics of the vultures in Azerbaijan. Anthropogenic threats to vultures and their nesting sites were determined during both point counts and line transect observations. Depending on the relief of the area of the nesting area, we have conducted the surveys on foot or by using various means of transport such as cars and horses.

Figure 1. The nesting places of breeding Griffon vulture, Egyptian vulture, Black vulture and Bearded vulture.

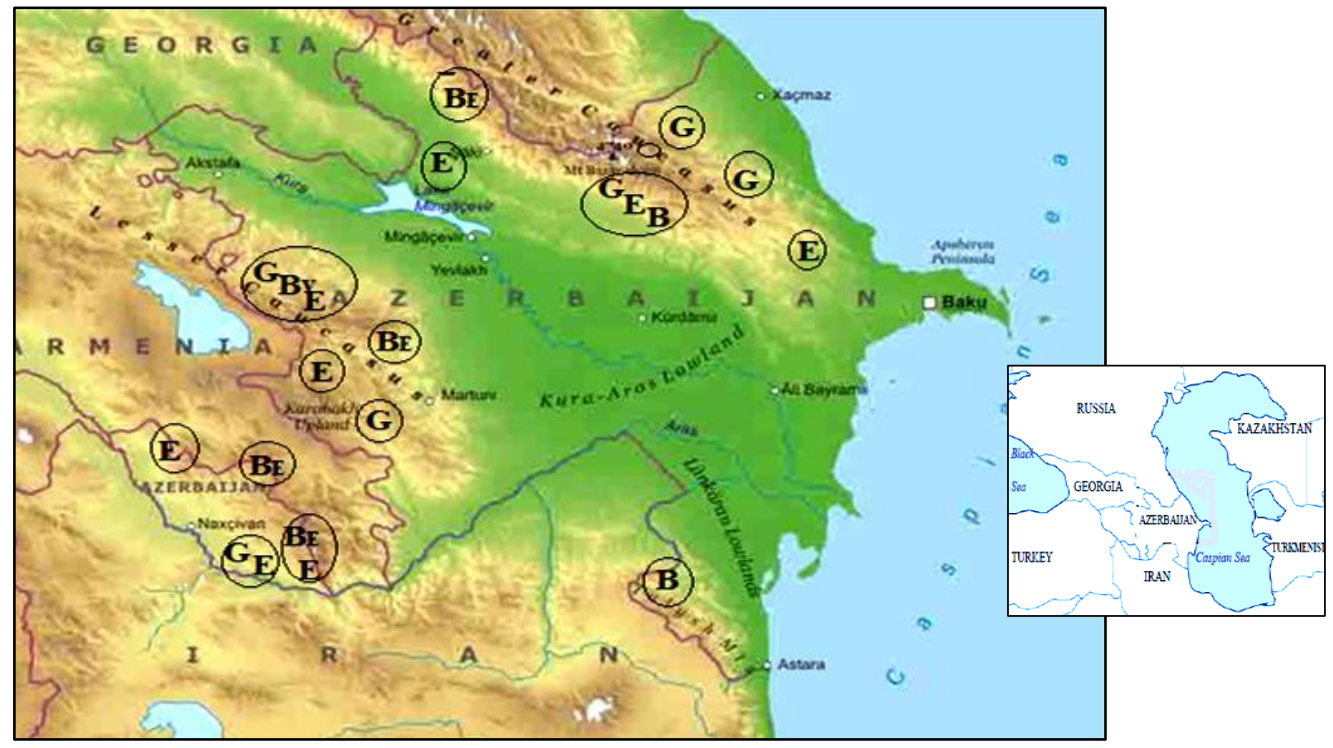

Note: G-Griffon vulture; B-Black vulture; E-Egyptian vulture; Be-Bearded vulture

Stations, log spots and routes were noted on maps and recorded by a GPS device to simplify further repeat navigation. We used Yukon $10 \times 50$ binocular and Kova TSN $601.20 \times 60$ telescopes and As an on-site data logger, we used Alsten $\times 2$ portable recorder.

\section{Statistical analysis}

The impact of the food supply and anthropogenic threats on the national population dynamics of 4 species in $2004-2016$ were analyzed via SPSS software. The relationship between the decline in the number of livestock, conversion of pastures and abandonment of livestock farms, increase of cultivated land and decline in the number of each 4 species have been analyzed separately. The effect of anthropogenic factors such removing nestlings, direct persecution, on the populations of 4 species has been also evaluated. Statistical calculations were carried out according to the following formulas:

$$
t=\frac{\left|\overline{X_{1}}-\overline{X_{2}}\right|}{\sqrt{\overline{S^{2}}\left(\frac{1}{n_{1}}+\frac{1}{n_{2}}\right)}}
$$

Where: $\mathrm{X} 1$ and $\mathrm{X} 2$ - the average size of the first and second samples, respectively; $\mathrm{S} 2$ is a common variation. when the number of sample sizes are equal $(n 1=n 2)$, the common variation is studied by this formula:

. S2 $=\frac{S_{1}^{2}+S_{2}^{2}}{2}$

If the number of samples is unequal $(n 1 \cdot n 2)$, the common variation is calculated by the following formula:

$\overline{S^{2}}=\frac{S_{1}^{2}\left(n_{1}-1\right)+S_{2}^{2}\left(n_{2}-1\right)}{n_{1}+n_{2}-2}$

S12və S22 are variations of the first and second samples. 
Data on the number of domestic animals, which is the primary food source, as well as the number of livestock farms and land use data were obtained from the State Statistics Committee.

\section{Results and Discussion}

\section{Nesting locations}

We found 4 species of vultures, nesting in 11 geographical regions out of 17 . All of those regions are located in Lesser Caucasus, Great Caucasus and Talysh mountains.

We identified 43 nesting sites belonging to 4 species in 2004. The overall figure dropped to 33 sites in 12 years. Our results reveals that $60.6 \%-i(n=20)$ of nesting locations were found in Leasser Caucasus, $36.3 \%-i(n=12)$ in Great Caucasus, $3.0 \%-i(n=1)$ in Talysh mountains. All 4 vulture species (Griffon vulture, Black vulture, Egyptian vulture, Bearded vulture) breed in Lesser and Great Caucasus. In Talysh mountains there only black vultures (Table 1).

Nests are found to be situated in various altitudes from sea level. The nests of Egyptian vultures are located minimum $166 \mathrm{~m}$ and maximum $1849 \mathrm{~m}$ above sea level. The altitudinal interval of Griffon vulture is $182-1645 \mathrm{~m}$. It is $363-1486 \mathrm{~m}$ for Black vulture. The nest sites of Bearded vultures are found at higher altitudes, between $1216-2574 \mathrm{~m}$.

It should be noted that in other countries vultures nest in various altitudes and objects depending on relief. Vultures nesting in rock cracks of 1.6-100 m high, on ground and on trees was noted (Karimov, 2016).

The number of nests and distances between them forms clusters in Azerbaijan. The nests of Bearded vulture are located 10-20 km far from each other. However Griffon and Black vultures breed colonially and Egyptian vultures, although not breeding in colonies, they can form breeding clusters. In each colony the average number of breeding pairs were $9.5 \pm 6.5$ pairs for Griffon vulture, 7.5 \pm 4.5 pairs for Black vulture and the Egyptian vulture cluster had $6.5 \pm 4.5$ pairs in 2016 .

The distance between the nests varied between $500-2000 \mathrm{~m}$ for Black vulture, 20-2000 m for Griffon vulture and 10-1000 m for Egyptian vulture. $38.6 \%-i$ ( $n=56$ pairs) of 145 couples belonging to 4 species nest at a height of $1000-2000 \quad m, 57.9 \%-i(n=84$ par) in mountainous areas up to $1000 \mathrm{~m}$. Only Bearded vulture (3.4\% or 5 par) nests at a height of $2000 \mathrm{~m}$.

Table 1. The number of nesting places of vultures and breeding couples.

\begin{tabular}{|c|c|c|c|c|c|c|}
\hline \multirow[t]{2}{*}{ Species } & \multicolumn{2}{|c|}{$\begin{array}{l}\text { Great Caucasus } \\
\text { mountains }\end{array}$} & \multicolumn{2}{|l|}{$\begin{array}{l}\text { Lesser } \\
\text { mountains }\end{array}$} & \multicolumn{2}{|c|}{ Talysh mountains } \\
\hline & $\begin{array}{l}\text { The } \\
\text { number } \\
\text { of } \\
\text { nesting } \\
\text { locations }\end{array}$ & $\begin{array}{l}\text { The } \\
\text { number } \\
\text { of } \\
\text { breeding } \\
\text { pairs }\end{array}$ & $\begin{array}{l}\text { The } \\
\text { number } \\
\text { of nesting } \\
\text { locations }\end{array}$ & $\begin{array}{l}\text { The } \\
\text { number } \\
\text { of } \\
\text { breeding } \\
\text { pairs }\end{array}$ & $\begin{array}{l}\text { The } \\
\text { number } \\
\text { of } \\
\text { nesting } \\
\text { locations }\end{array}$ & $\begin{array}{l}\text { The } \\
\text { number } \\
\text { of } \\
\text { breeding } \\
\text { pairs }\end{array}$ \\
\hline $\begin{array}{l}\text { Griffon } \\
\text { vulture }\end{array}$ & 5 & 46 & 3 & 15 & - & - \\
\hline Egyptian vulture & 5 & 36 & 10 & 23 & - & - \\
\hline $\begin{array}{l}\text { Black } \\
\text { vulture }\end{array}$ & 1 & 12 & 1 & 3 & 1 & 1 \\
\hline $\begin{array}{l}\text { Bearded } \\
\text { vulture }\end{array}$ & 1 & 1 & 6 & 8 & - & - \\
\hline Total & 12 & 95 & 20 & 49 & 1 & 1 \\
\hline
\end{tabular}

\section{Number and dynamics}

In 2004, 171 pairs of vultures were identified, with 71 pairs of Griffon vulture, 68 pairs of Egyptian vulture, 22 pairs of Black vultures, 10 pairs of Bearded vulture. In subsequent years, the numbers have gradually decreased (Table 2). Over the past 13 years the decrease in the total decline of 4 vulture species was 15.3\%, from 171 to 145 pairs, mostly in Greater Caucasus and Talysh mountains.

The size of population of decline on species levels are $27.3 \%$ in Black vulture, $14.1 \%$ in Griffon vulture, $13.3 \%$ in Egyptian vulture and $10.0 \%$ in Bearded vulture. Currently, Griffon vulture represents the largest vulture population in Azerbaijan followed by Egyptian vulture. In 2004, Griffon vultures constituted $41.5 \%$ of all vultures. The observations from the beginning of the century had also indicated, the population of Griffon vultures were significantly larger than that of Black, Bearded and Egyptian vultures (Patrikeev, 2004). In 19th century it was noted that Griffon vultures nested in Talysh mountains, Gobustan as well as in Zagatala (Mustafaev, 2012). We found out that, Griffon vultures do not nest in those areas and the previously known colonies are currently unoccupied. For instance, in years 2004-2006, the colony around Kashy village of Guba district in Greater Caucasus, held 20-21 pairs. In 2016 only 6 pairs were recorded. Within 13 years, the number of breeding pairs in Sudur village of Gusar district had declined from 11 to 3 pairs. In Talysh mountains, Zagatala reserve and Gobustan not only Griffon vultures but also Bearded, Egyptian lost their breeding capabilities and do not nest there any longer. The breeding pairs of Black vulture lowered to 1 from 3 , 12 from 16 in Turyanchay reserve. As for Egyptian vultures, they felt to 6 from 11 pairs. We studied the factors causing loss of 
biotopes and number shrinking and determined that, gradual limitation of food supply and anthropogenic threats resulted directly or indirectly in a population decline in 2004-2016 (Table 3).

Table 2. The population changes of vultures in 2004-2016s

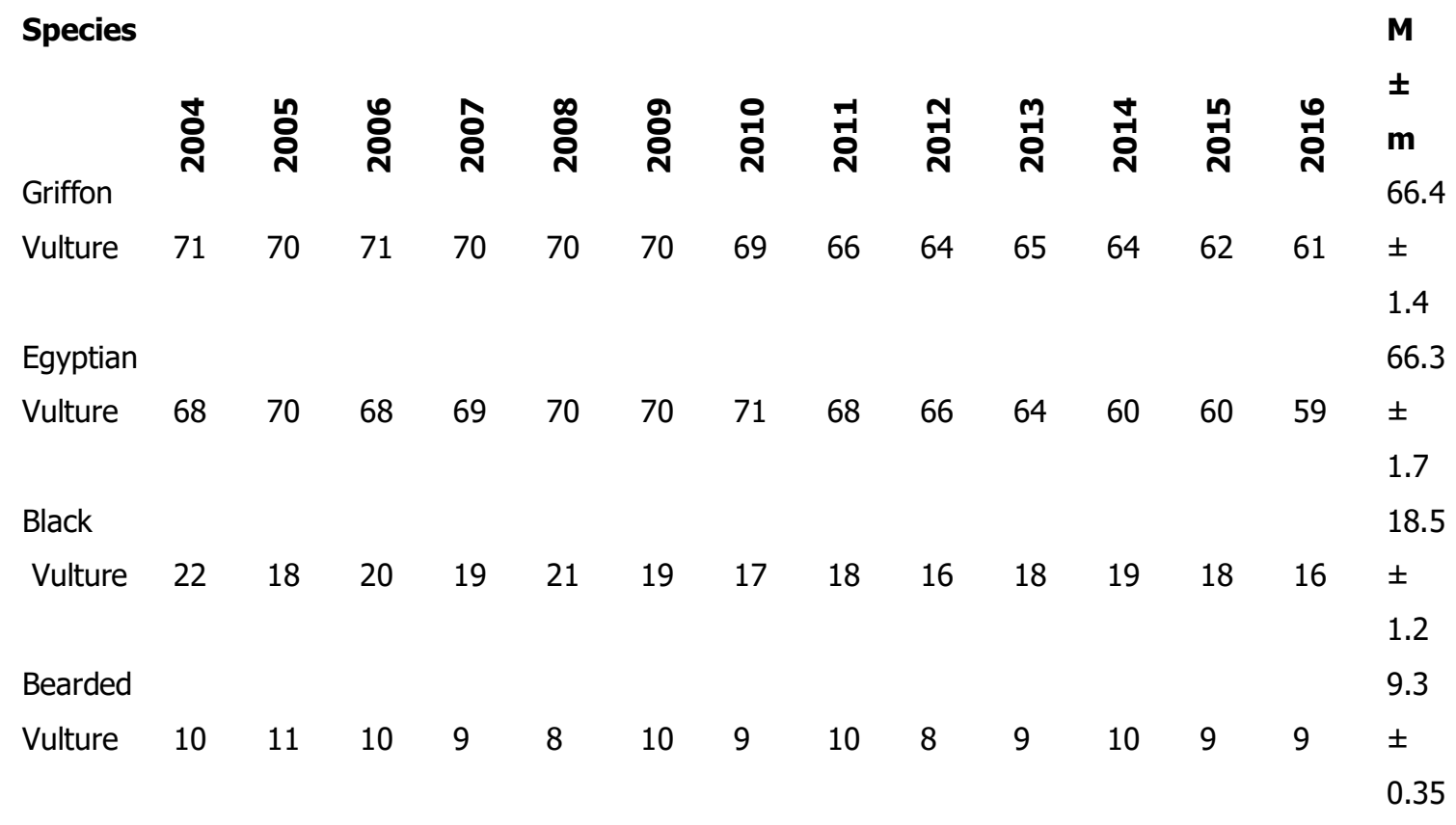

Table 3. The Primary drivers of vulture population decline (Paired Samples Test).

\begin{tabular}{|c|c|c|c|c|c|c|c|c|}
\hline \multirow[t]{2}{*}{ Factors } & \multirow{2}{*}{$\sum_{26.91}^{\frac{5}{0}}$} & \multirow{2}{*}{ 莡 } & \multirow[t]{2}{*}{$\begin{array}{l}\text { Std. } \\
\text { error } \\
\text { mea } \\
\text { n }\end{array}$} & $\begin{array}{l}95 \% \\
\text { confid } \\
\text { Inter } \\
\text { the di }\end{array}$ & $\begin{array}{l}\text { oce } \\
\text { of } \\
\text { erence }\end{array}$ & t-test & \multirow[t]{2}{*}{$\begin{array}{l}\text { Degree } \\
\text { of } \\
\text { freedom } \\
=d f\end{array}$} & \multirow[t]{2}{*}{$\begin{array}{l}\text { Statisticall } \\
\mathbf{y} \\
\text { significant } \\
\text { level }\end{array}$} \\
\hline & & & & $\begin{array}{l}\text { Lower } \\
32.10\end{array}$ & $\begin{array}{l}\text { Upper } \\
21.73\end{array}$ & -10.84 & & \\
\hline Pigs & 12.17 & 75.44 & 22.62 & 17.45 & 66.89 & -5.26 & 11 & $<0.0001$ \\
\hline Donkeys & 45.09 & 33.65 & 94.16 & 47.16 & 43.02 & -46.73 & 11 & $<0.0001$ \\
\hline Mules & 65.75 & 14.09 & 4.07 & 56.81 & 74.70 & 16.17 & 11 & $<0.0001$ \\
\hline Sown area & 16.00 & 16.68 & 45.49 & 17.35 & 15.60 & 33,73 & 11 & $<0.0001$ \\
\hline $\begin{array}{l}\text { The number } \\
\text { of the farms }\end{array}$ & 23.50 & 50.19 & 16.18 & 27.31 & 19.60 & -14.29 & 9 & $<0.0001$ \\
\hline $\begin{array}{l}\text { The use } \\
\text { of lands }\end{array}$ & 39.60 & 13.90 & 39.80 & 48.30 & 30.90 & -9.9 & 9 & $<0.0001$ \\
\hline $\begin{array}{l}\text { Anthropogenic } \\
\text { factors }\end{array}$ & 1.61E2 & 10.99 & 3.05 & 15.13 & 16.42 & 52.72 & 12 & $<0.0001$ \\
\hline
\end{tabular}

\section{Factors affecting the distribution range and population size of vultures}

Distribution range and population size of Griffon vulture, Black vulture, Egyptian vulture and Bearded vultures in Azerbaijan were influenced by two factors. One of them is available breeding habitat and the other is food supply. Historical colonization of these species in Azerbaijan was induced by similar geographical processes in Eurasia. The main factors enabled the settlement of these birds in the Azerbaijan in the ancient times was the formation of mountain chains such as Pyrenes - Alpes - Carpathian - Caucasus Himalayas - Tibetan mountain landscapes in Eurasia (Byme, 1975) and the rapid development of the megafauna (large herbivores and predatory mammals) in Pleistocene (Burchak-Abramovich and Aliyev, 1981; Boev, 2010) and the development of cattle herding in mountain pastures, during the middle ages (Narimanov, 1987). Local orography, petrophilia and mosaic shape of phytocenosis created favorable conditions for settlement of these species in mountain landscapes. Thermic air flows of mountain valleys enable vultures to soar longer. Secondly, vultures having 3 meters long wings with 2-12 kg of weight make use of rocks and rock exits as jump-off spots for lifting to sky. Thirdly, petrophilia (naked rocks, stony slopes, valleys, river valleys) of these mountain landscapes 
enable the birds pre-screen wide areas and locate food (where there are more animal losses and hence, corpses are easily seen). Fourthly, location of nests in 30-70 meters of altitude of steep rock make them unreachable for mammals. In Azerbaijan, the Bearded vultures begin breeding in late February, Black and Griffon vultures in early march, whereas Egyptian vulture start the courtship in early April. Snow falls in mountains and there are strong winds with air temperature of $+5-12^{\circ} \mathrm{C}$ during these months. Bearded, Griffon and Egyptian vultures nest in south looking dry rifts and caves in order to protect from negative climate factors. The Black vultures nest on trees grown in south expositions without wind and snow. This protects the nests from cold north winds, rainfall, and enables the vultures to nest in February-March. It should be noted that, Black vulture and Griffon vulture begin to nest 25-30 days earlier (Appak, 2001) in the Crimea being located in the north of Azerbaijan. Otherwise, juveniles would leave the nest in an unfavorable autumn period.

More birds tend to breed in lower altitudes around $1000 \mathrm{~m}$ compared to alpine areas found around $3000 \mathrm{~m}$. This is due to the increase of petrophilia of the arid condition at the lower altitudes. Egyptian vulture, Griffon vulture and Black vulture prefer the areas with dry climate. Only Bearded vulture prefers sites higher than $2000 \mathrm{~m}$. This is due to absence of bearded vulture's competitors in the areas higher than $2000 \mathrm{~m}$ in the subalpine and alpine zones along with late degradation of carrions in moderate climatic conditions. Bearded vulture prefers fresh carrions (Abuladze, 1989) don't often wander to lower altitudes $500 \mathrm{~m}$ to look for food (Belik, 2008). Egyptian vulture, Griffon vulture and Bearded vulture prefer nesting in the rocks, crevices and caves, 30-70 $\mathrm{m}$ higher than ground in Azerbaijan. Abundance of caves and rifts in rocks allows the species to use them in rotation. Black vulture nests only on Juniper trees (Juniperus sp.) in Azerbaijan. As in the Caucasus region (Abuladze et al., 1995), unoccupied nesting territories and locations are also sufficiently available in Azerbaijan and even some pairs use 2 nests. There several reasons fro Black Vultures to prefere Juniper Trees. Juniper trees grow on inaccessible rift, rocky and stones and are strong enough to support a nest of $2 \mathrm{~m}$ diameters on its branches.. Moreover, Juniper trees release $30 \mathrm{~kg}$ of phytoncide in a day, by nesting on a juniper tree, they protect themselves and their nestlings. Since there're plenty of available nesting locations, juniper trees cannot be regarded as a limiting factor for cinereous vultures in Azerbaijan (Karimov, 2015).

Black vultures were found to nest on pine trees (Pinus sp) in the Crimea, on oak trees (Quercus sp.) in Spain and Greece and on almond trees in Uzbekistan (Amigdalus bucharica), Middle Asia and Mongolia, it also nest on rocky cliffs and on the ground (Karimov, 2016). The Vultures breeding in Azerbaijan have kept the ecological and ethological adaptation characteristics of their ancestors and kept their adaptation to rocky biotopes in Azerbaijan territory. The reason for this is existence of suitable biotopes for breeding in mountains. This applies to south part of Great Caucasus, Lesser Caucasus and Talysh mountains ( Karimov, 2015).

Over the past 12 years, anthropogenic threats directly or indirectly have reduced the populations of 4 vulture species. When we identify these drivers, we can reach a conclusion by looking at the following figures. During the 12 years long period of this study, the total number of cattles had declined from 298,649 to 242,494 individuals, the total number of donkeys from 37,857 to 35,816 , and the total number of pigs had decreased significantly from 18,611 to 5,217 individuals where as the number of mules remained mostly stable from 136 to 103 . We have witnessed a similar decline in scavenger populations such as Griffon vultures had decreased from 71 to 61 pairs, the population of Black vulture ranged from 22 to 16 pairs, the number of Egyptian vulture has decreased from 68 to 59 pairs, and the number of Bearded vulture has declined from 10 to 9 pairs.

Statistical calculations have shown that the decline of the number of animals affects the number of species of birds ( $p<0.0001)$. On the contrary, the number of horses, camels, sheep, goats has remained the same over the past 12 years. Therefore, no negative effects of these factors on the number of birds were identified The increase of cultivated land increased from 1041542 to 1585389 ha. On the contrary, the number of livestock farms have declined from 3248 to 1534 enterprises and graze lands have shrunk from 62,216 to 33,363 ha. This has led to a reduction of the available foraging habitat. Removal of chicks from the nest, the persecution and poisoning of birds have affected all four species $(P<0.0001)$. Some individuals of Black vulture and Griffon vulture migrating to Arabian Peninsula from Caucasus are reported to perish from starvation on their way back (Ghavashelishvili, 2011). Note that the threats resulting in decline of vultures in Azerbaijan territory do not originate only from Azerbaijan. It was found that some individual Egyptian vultures migrating to Africa (Ethiopia) and Oman died in their wintering grounds and on the way back because of direct persecution, electrocution, poisoning and starvation. (Angelov et al., 2012; Ankumarev et al., 2014).

\section{Conclusion}

All four species are listed in the Red Book of Azerbaijan however, this passive method doesn't enforce ör secure the conservation of vultures. Therefore, regular monitoring and proper conservation projects for vultures in Azerbaijan territory must be carried out. There are suitable nesting habitat for vultures in Azerbaijan and nesting habitat should not be considered as a limiting factor.

In order to reduce human pressure during the breeding season nesting localities should be guarded during the bleeding season namely from March to July each year. This sites should be identified as "nature's monuments' and protected by ecology and natural resources ministry. During chick rearing period, supplementary feeding facilities should be established and additional food should be provided in order to increase the breeding success.

\section{Acknowledgements}

We express our gratitude to the staff of the local organizations of Ecology and Natural Resources Ministry for their assistance in conducting the inventory.

\section{References}

Abuladze, A. V. (1989). Ob osobennostyakh ucheta khishchnykh ptits v gorakh // Vsesoyuznaya soveshchaniya po probleme kadastra i ucheta zhivotnogo mira: Tezizy CH. 1. Ufa, 1989: 377-378 (In Russian).

Abuladze, A., Rostiashvili, G., Eligulashvili, B., Shergalin, J. (1995). Present status of Black Vulture's populations in Caucasus. International Conference Bird Numbers 1995, (25-30 September 1995, Parnu, Estonia).. 
Angelov, L., Hashimi, A., Oppel, S. (2012). Persistent electrocution mortality of Egyptian vultures (Neophron percnopterus) over 28 years in East Africa. Bird Conservation International 1-6. https://doi.org/10.1017/S0959270912000123

Ankumarev, V., Dobrev, V., Abebe, Y., Popgeorgiev, G. (2014). Congregations of wintering Egyptian Vultures Neophron percnopterus in Afar, Ethiopia: present status and implications for conservation. Ostrich, 85 (2): 139 -145.

Appak, B. A. (2001). Black Vulture in the Crimea. Journal Berkut 10 (1): 52-62 (In Russian with English summary).

Belik, V. P. (2008). The Lammergeier in the Northern Caucasus: distribution and numbers. Journal Strepeth, 6 (2): 63-65 (In Russian with English summary).

Boev, Z. (2010). Prof. Nikolay Burchak-Abramovich's private collection of Late Pleistocene birds from Binagada (Azerbaijan) - a lost treasure of avian palaeontology: general review of the exploration of the exploration of the site and its scientifi $\mathrm{C}$ value. In: Bauernfeind E, Gamauf A, Berg HM and Muraoka Y eds. Proc.5th International Meeting of European Bird Curators (January 2010, Natural History Museum of Vienna). Vienna: 169-198.

Botha, A. J., Andevski, J., Bowden, C. G. R., Gudka, M., Safford, R. J., Tavares, J. and Williams, N. P. (2017). Multi-species Action Plan to Conserve African-Eurasian Vultures. CMS Raptors MOU Technical Publication No. 5. CMS Technical Series No. 35. Coordinating Unit of the CMS Raptors MOU, Abu Dhabi, United Arab Emirates.

Byme, R. L. (1975). Orniogeograficheskoye issledovaniye gornoy strany Yuzhnoy Palearktiki. Stervyatniki yuzhnoy Palearktiki. Moskovskiy Gosudarstvenniy Universitet: 129 -138 (In Russian).

Buechley, E. R., Sekerciorlu, C. (2016). The avian scavenger crisis: looming extinctions, trophic cascades and loss of critical ecosystem functions, Biological Conservation, 198, 220-228

Burchak-Abramovich, N. Y. (1972). Binagadian fauna and flora. Sessiya, posviashchon $\neg$ naya 100-letiyu so dnya rozdeniya akad. A. Borisyaka. Paleontological Institute of the NAS of the USSR, Moscow: 73-76 (In Russian).

Carrete, M., Bortolotti, G., Sánchez-Zapata, J., Delgado, A., Cortés-Avizanda, A. (2013). Stressful conditions in African wintering areas in the endangered Egyptian vulture. Journal Animal Conservation 16 (3): 353-358. https://doi. org/ 10.1111 /acv.12001

Cortés-Avizanda, A., Blanco, G., DeVault, T., Markandya, A., Virani, M. (2016). Supplementary feeding and endangered species: benefits, caveats and controversies. Journal Frontiers in Ecology and the Environment 14 (4): 191-199. https:// digital commonsunl. edu/icwdm_usdanwrc/1812

Donázar, J. A., Cortés-Avizanda, A., Carrete, M. (2010). Dietary shifts in two vultures after the demise of supplementary feeding stations: consequences of the EU sanitary legistation. European Journal Wildlife Research 56: 613-621. DOI 10.1007/s 10344-0090358-0

Ghavashelishvili, L. (2011). Where do Vultures Fly from Their Natal Areas in the Caucsus? Results of 10-Year-Long Radio-Satellite Tracking/ International conference 26-29 october "The Birds of Prey and Owls of Caucasus",Tbilisi: 18-19.

Karimov, T. (2015). Main limiting factors affecting biological parameters of necrophage birds. The Journal of V.N.Karazin Kharkiv National University 1153 (24): 68-73. http://seriesbiology.univer.kharkov.ua/ukr/24 (2015)/pdf/68.pdf

Karimov, T. (2016). Limiting Factors Affecting Reproductive and Demographic İndicators of Black Vulture (Aegypius monachus). Journal of Applied Environment and Biological Sciences 6 (1): 17-22.(https://www.textroad. Com/pdf/JAEBS/J Appl Environ Biol. Sci,6 (1) 17-22.

Katzenberger, J., Tabur, E., Sen, B., Isfendiyaroglu, S. (2017). No short-term effect of closing a rubbish dump on reproductive parameters of an Egyptian Vulture population in Turkey. Journal Bird Conservation International 1-12. https://doi. org/10.1017/ S0959270917000326.

Margalida A, Benitez R, Sánchez-Zapata J, Ávila E, Arenas R et al. (2012). Long-term relationship between diet breadth and breeding success in a declining population of Egyptian Vultures Neophron percnopterus. Journal Ibis 154: 184-188. doi:10.1111 /j.1474-919X.2011.01189 x.

Moreno-Opo, R., Arredondo, A., González, L., Margalida, A. (2015). Manipulating size, amount and appearance of food inputs to optimize supplementary feeding programs for European vultures. Journal Biological Conservation 181: 27-35. http://dx.doi. org/10.1016/j.biocon. 2014. 10.022

Mustafaev, G. T. (2012). (Ed.Talibov T) Interrelations of vertebrates and people. Baku, Elm: 114-118 (In Russian with English summary).

Ogada, D., Shaw, P., Beyers, R., Thiollay, J., Beale, C. (2016). Another Continental Vulture Crisis: Africa's Vultures Collapsing toward Extinction. Conservation Letters 9: 89-97. DOI: 10.1111/conl.12182

Oppel, S., Dobrev, V., Ankumarev, V., Saravia, V., Bounas, A. (2016). Assessing the effectiveness of intensive conservation actions: Does guarding and feeding increase productivity and survival of Egyptian Vultures in the Balkans? Journal Biological Conservation 198: 157-164. http://dx.doi.org/10.1016/j.biocon. 2016.04.0020006-3207/

Osmolovskaya, V. İ., Formozov, A. N. (1952). Metody uchota chislennosti i geograficheskogo raspredeleniya dnevnykh i nochnykh khishchnykh ptits. V sbornike metody uchota chislennosti i geograficheskogo raspredeleniya nazemnykh pozvonochnykh. M.1952: 68-96 (In Russian).

Patrik, M. (2004) The birds of Azerbaijan, Pensoft Publishers, Sofia-Moskva:180-183.

Sara, M., Di Vittorio, S. (2009). StatusofEgyptian Vulture (Neophron percnopterus) in Sicily. Journalof Raptor Research 43:66-69. https://doi.org/10.3356/JRR-08-27.1

Narimanov, I. G. (1987). Kul'tura drevneyshego zemledel'chesko-skotovodcheskogo naseleniya Azerbaydana. Baku: 10-19 (In Russian).

Sultanov, E. H., Karimov, T. A, Isayev, Sh. A. (2008). Ornitologicheskiy monitoring. Khazarskiy Universitet, Baku: 7-10 (In Azeri).

\section{Citation:}

Tahir, K., Arzu, M. (2019). The Status of Vultures Neophron Percnopterus, Gypaetus Barbatus, Gyps Fulvus, Aegypius Monachus(Accipitriformes) In Azerbaijan. Ukrainian Journal of Ecology, 9(4), 565-570.

(cc) Br $\mathrm{EY}$ This work is licensed under a Creative Commons Attribution 4.0. License 